\title{
Southeast Asian Press Coverage of Terrorism and the Bali Bombing
}

\author{
SONIA AMBROSIO DE NELSON
}

\begin{abstract}
The war against terrorism is being carried out not only in Afghanistan where it was first declared but also in the media around the world. Southeast Asia became a focus of international attention after the U.S. administration identified the region as the second front in the fight against terrorism following the attacks in the United States on 11 September 2001. The perception that the region is a cradle for terrorism was reinforced by the Bali bombing in October 2002. The event was the first major terrorist attack after 11 September, and the worst act of violence against foreigners in Indonesia, a country that has been under continuous international pressure to be decisive in the fight against terrorism. Although the media can function as the source of people's information, it can provide interpretations of the social construction of ideas and images. Like the media in all parts of the world, the media in Southeast Asia function within some form of governmental, societal, and economic constraints. Journalists are encouraged to support their governments' efforts to develop the nation and instil a sense of national identity. In such a setting journalists, consciously or not, end up not only reflecting but also spreading the dominant view of the society's elite. This transnational comparative study involving three mainstream English-language newspapers from Indonesia, Malaysia and Singapore examines the reportage of the Bali bombing."
\end{abstract}

\section{Introduction}

The terrorist attacks against targets in the United States on 11 September 2001 and the subsequent 'war on terror' have encouraged scholars to study the role of the media in addressing controversial issues such as terrorism and religion. Islamic extremists are held responsible for the attacks in the United States; this perception has contributed to an increase in the extent to which the international media associate Islam with acts of political violence.

The Southeast Asian region ${ }^{1}$ with its ethnic, cultural and religious complexity offers a unique setting ${ }^{2}$ to study the implications of 11 September, the global fight against terrorism and the response of regional media. The terrorist attacks on the Indonesian Island of Bali, one year 
after 11 September, brought world attention to the region. Southeast Asia has the world's largest concentration of Muslims ${ }^{3}$ and has been described by the United States Administration as the second front in the war against terrorism.

\section{Objective}

The paper looks at how the English-language newspapers, The Jakarta Post from Indonesia, New Straits Times from Malaysia and The Straits Times from Singapore, reported on the Bali bombing and addressed terrorism in their reportage.

\section{Terrorism}

There is a lack of global consensus on what constitutes terrorism (Atkins 1992; Held 1997; Nacos 2000; Jenkins 2003; Sorel 2003). The ambiguity surrounding the expressions terrorism and terrorist means there is often controversy over the application of the terms, which are widely accepted to have pejorative connotations (Sorel 2003; Ruby 2002; Carruthers 1996). This lack of consensus has profound implications for the media because it leaves them open to charges of inconsistency when reporting on those responsible for acts of political violence (Iyer 2003: 107).

Despite different definitions of terrorism, they are traditionally oriented around two concepts: the use of violence, and a political aim behind the terrorist act. Virginia Held (1997) and Stephen Atkins (1992) summarize the definitions of terrorism as a specific form of political violence that aims to create fear within a population. The political use of violence to cause fear is a tactic that has been used by terrorists as well as authoritarian and totalitarian governments.

However, after the events in the United States in 2001, perceptions of terrorists have changed from perpetrators of violent acts for political ends, to a general, static threat (Stenvall 2003). The threat of terrorism has become permanent. It has the potential to cause continuous fear, and it therefore allows the U.S. administration and other governments involved in the fight against terrorism to create a sense of emergency and to justify new policies and requests for funding.

For the purpose of a broader understanding of the terms used in this paper - terrorism, terrorist - it is worth keeping in mind that definitions and usage of terms reflect the interests of those doing the defining and labeling. Definition reflects particular historical eras, intellectual professions, partisan positions, and ultimately the exercise of power (Sederberg 1989: 3). Those who are able successfully to attach the ter- 
rorist label to their opponents will have indirectly persuaded others to adopt their view, or at least to reject the terrorists' view. This drawing of boundaries between what is legitimate and what is illegitimate sets the agenda for political debate (Sederberg 1989: 4; Carruthers 1996: 110113). Thus, the definitions used in this project are not received as truths but are conceptual tools required for the analysis.

\section{Questions}

The war against terrorism is being waged not only in places where police and military operations are under way, such as Afghanistan and the Middle East, but also in the media around the world.

Although the media are a source of information, they also provide interpretations. Facts and empirical observations are seldom disinterested or transparent; they always require interpretations (Manning 1999; Edelman 2001). The media in Indonesia, Malaysia and Singapore are strongly influenced by the experience of nation-building (Nain 2002; Khee 2000; Hassan 2001). Therefore, how a problem is understood and how it is defined involves alternative scenarios, each with its own facts, value judgment, and emotions. (Edelman 2001: 11).

Question 1: How were the perpetrators of the bombing described in the stories? Was there characterization of the perpetrators?

Question 2: What tendencies did the newspapers' coverage reveal?

\section{The Media in Southeast Asia}

The media sector in Southeast Asia, like the media in all parts of the world, function within some form of governmental, societal, and economic constraints. I base my argument on Hatchen's (1996: 14) viewpoint that even the most independent press system must deal with varying degrees of regulation by political authority. Hence, the basic question for the purpose of this paper is not to inquire whether governments in Southeast Asia control the press but to understand the nature and extent of that control as well as the role of commercial interests.

The concept of media freedom in the region is central to the understanding the political role of the media. ${ }^{4}$ Censorship is practised at various levels in the media in Southeast Asia (Chongkittavorn 2002) as a way to 'sacrifice freedom temporarily to achieve rapid economic development' (Kingsbury 2001: xv). The Association of Southeast Asian Nations or ASEAN encourages a model of journalism by calling on journalists to support their governments' efforts to develop their nations 
and instil a sense of national identity in citizens from different ethnic, religious, and language groups (Menon 1994:1).

\section{The Media in Indonesia}

Indonesia is witnessing a soft opening in media freedom. The main agent of change is the development of industrial capitalism (Heryanto and Adi 2001; Uhlin 1997). New publications ${ }^{5}$ are flourishing, while the big, old companies have maintained their dominance.

During the Suharto era, from 1965 to 1998, he made sure the media were limited in their criticisms of the New Order. Government control was based on a blend of economic development, military influence, highly centralized power structures, and strict limits on popular political participation (McCargo 2003). The state has now lost nearly all its paternalistic control of the mass media. Nevertheless, it maintains some power in regulation and licensing even as groups of journalists have worked together to abolish repressive media legislation and amend the constitution to guarantee press freedom (Harsono 2000).

Lately, there have been cases of visa rejections for foreign journalists intending to cover the government's military action in the separatist province of Aceh. The government has also used the American embedding style of journalism, which only allows approved reporters to accompany troops and cover events in Aceh. ${ }^{6}$

\section{The Media in Malaysia}

Malaysia has one of the earliest histories of journalism in the region, dating back to the British colonial period. After independence in 1957, radio and newspapers gained prominence as useful tools of national development. It was assumed that the function of the media was to help the government impart information and disseminate its policies for the betterment of the population in general (Anuar 2000: 99).

The government wanted the press to help foster national unity in two ways. One was to avoid reporting or raising issues that would inflame racial sentiment in the population. Secondly, the press was to be an agent of mobilization during the launching of policy campaigns or during social intervention programs (Print Media in ASEAN 1998; Anuar 2000).

From the 1970s, the media have been designed to play the role as a partner of the government in promoting unity and development. It was also during this period that the press system began to take shape with 
various laws and regulations being enacted. Most of them, if not all, are still in effect. In Malaysia, much of the media is still under government control (Nain 2002: 119, 121). It is not uncommon for the government to use the Internal Security Act against journalists.

\section{The Media in Singapore}

Development journalism is one of many characterizations of the media in Singapore (Wong 2004). Development journalism prescribes a theoretical model of state-media dynamics, which is cooperative in nature and serves the objective of national development above all else (Heng 2002: 6). When dealing with print and broadcast media, Singapore authorities have been able to tailor their political interventions narrowly so that these actions have not smothered their economic priorities (George 2003). Media freedom has been markedly absent in Singapore, says Garry Rodan, who argues that the government 'remains determined to use what power it has to curtail critical and investigative media reporting on social and political issues' (Rodan 2000: 219).

The press system is maintained by tight legal controls. Licensing and national security laws are used (George 2002; Rodan 2000, 2003); press laws require all newspapers to be licensed: while journalists can be fined or jailed if they breach laws on the contempt of court or contempt of parliament. Libel laws induce writers to take extreme care with any comments that could be claimed to hurt officials' reputations. Newspaper companies must be locally owned and publicly listed, and their shares divided into ordinary and management shares. The government can select who holds management shares, enabling it to name the company's chairman and directors, and through them to ensure that the journalists appointed to senior gatekeeping positions are trustworthy (George 2002).

At the Media and Democracy in Asia conference in Kuala Lumpur, in September 2000, ${ }^{7}$ the president of the Singapore Confederation of ASEAN Journalists, Ivan Lim said that his government exercised effective control of the media and that newspaper editors were also co-opted to serve in the nation-building political agenda of the ruling People's Action Party.

Despite media control, the advanced infrastructure of Singapore makes the place the ideal base for reporting on Southeast Asia: some seventy-one foreign news organizations are based in the city-state (Rodan 2000). Many of the wire services emphasize business reporting and avoid local social or political issues. ${ }^{8}$ 


\section{Religion}

Over two hundred million Muslims live in Southeast Asia (Nakamura 2001), making it the geographic area in which the world's largest number of Muslims is concentrated. In many areas, Islam has become intertwined with pre-existing values and belief-systems associated with folk religion, Buddhism and Hinduism. Islam is closely associated with a strong sense of community (Esposito 1987). Esposito defines Islam as a brotherhood of believers based upon a shared faith whose identity, unity and solidarity is supposed to transcend all other loyalties (for example, family, tribal, and national), and this sense of association is strong among Muslims in Malaysia and Indonesia and the Philippines (Irwin 1966). Islam is the predominant religion in Malaysia and Indonesia. Singapore ${ }^{9}$ has the smallest Islamic population among the three countries studied in this paper, but has a vulnerable geographic position. This city-state has borders with Malaysia and Indonesia, and is prone to the social developments in the neighbouring countries (Acharya 2000: 3-6). Government leaders and intellectual classes of all three countries stress that Islam is a religion of peace and that Muslims in Southeast Asia are generally 'moderate'.

\section{Political Violence}

Every state in Southeast Asia has had at some stage a revolutionary organization that has had the explicit goal of overthrowing the prevailing political order (Kingsbury 2001). Before the discovery of a regional terrorist network, ${ }^{10}$ political violence associated with radical groups was considered an internal domestic issue. The groups were called insurgents, separatists, and bandits. For example, in Malaysia, members of the self-styled Malayan Races Liberation Army were officially designated 'communists' in 1952 as a result of the colonial administration's policy to lump 'bandits' with international communism (Carruthers 1996). A committee meeting ${ }^{11}$ decided that 'on no account should the term "insurgent", which might suggest a genuine popular uprising, be used'. In recent years, concern has grown over religiously inspired militancy by radical Islamic groups (Tan 2003). Now radical groups are seen as advocates of a pan-regional movement to create an Islamic state in the region (Thayer 2004). 


\section{Conceptual Framework}

This study requires an understanding of earlier relationships between East and West. The work of two writers has been chosen as the framework for this understanding. They are Edward Said and Karim H. Karim (2000), who argue that the western media portray Islam as being associated with violence.

Edward Said (1997) claims that for centuries Occidental reactions to Islam have been dominated by a radically simplified type of demoniac perception. He views the oil crisis of the 1970s and the Iranian occupation of the American embassy in Teheran in 1978 as the turning points for an unsympathetic portrayal of Islam by the Western media, and the manipulation of the meanings of the terms 'Islam' and 'Muslim'.

Karim H. Karim (2000) tried to trace the origins of the Oriental theorists in European history. He discusses how the Latin Christian world started attributing features to its enemy while engaged in the Crusades (Karim 2000: 56). In Medieval dramaturgy Muslims were portrayed as 'the Other' (ibid. 188), 'the bad'. The concept of 'the Other' is found in contemporary news frameworks when the western media see themselves as Us, the good and see Muslims as 'the Other', the bad. The view of Muslims as a source of danger (to the West) has origins in Eurocentric discourses suggesting that Muslims were essentially gripped by violence, lust, and barbarism. These fundamental images have been regularly reproduced in contemporary popular culture such as film and television programmes and the press (ibid. 2; Jenkins 2003: 150).

John Esposito (2003) argues that the Western perception of Islam and Islamic movements remains a sensitive and explosive issue in Muslim countries. The use of sensationalist headlines and reports about Islam and events in the Muslim world hinders the public's ability to distinguish between the religion and the actions of extremists. It also reinforces the tendency to equate all Islamic movements with terrorism. In this context, it is important to consider the theories of Foucault (1978), Herman and Chomsky (1999) who discuss the manufacturing of consent around the concept of 'the Other. The manufacturing of consent involves such factors as the choice of report; volume and quality of coverage; and modes of handling favoured and inconvenient materials through placement, tone, and context.

Acts of violence are intrinsically newsworthy because they have an impact on people's lives. Nevertheless economic and political interests shape output in journalism. Croteau (2000) reminds us that while we must 
understand the influence of the media industry in our society, we must also recognize how economic and political constraints affect the media.

\section{Impact of 11 September}

Following the events of 11 September 2001, U.S. president George Bush declared ${ }^{12}$ Osama Bin Laden ${ }^{13}$ as the prime suspect. Bush went further, and a few days later, during a speech to Congress ${ }^{14}$ said, 'Our war on terror begins with $\mathrm{Al}$ Qaeda, but it does not end there. It will not end until every terrorist group of global reach has been found, stopped, and defeated'. He identified the 'heirs of all the murderous ideologies of the $20^{\text {th }}$ century', the terrorists who 'practice a fringe form of Islamic extremism' that has been 'rejected by Muslims scholars and the vast majority of Muslims clerics'. He declared, 'This is the world's fight. This is civilization's fight. This is the fight of all who believe in progress and pluralism, tolerance and freedom. Every nation, in every region, now has a decision to make. Either you are with us, or you are with the terrorists. From this day forward, any nation that continues to harbour or to support terrorism will be regarded by the United States as a hostile regime'. Following this declaration, the United States turned its attention to radical Islamist groups in Southeast Asia, particularly those in the Philippines, Indonesia, Malaysia and Singapore. Countries in the region were pressed to arrest suspected terrorists. Southeast Asian governments have to balance their security concerns with domestic political considerations, so the countries' response to both the terrorist threat and the U.S. campaign varied according to their domestic policies and a concern about their own stability.

\section{Analyzing the Bali bombing press coverage}

The Jakarta Post is owned by a business conglomerate. The broadsheet is widely available in top-class hotels and tourist centers in the capital. The newspaper faces stiff commercial competition but it has a strong position with the expatriate and international communities.

The New Straits Times is a broadsheet paper mainly used by government officials to express policies and their views on domestic and international affairs. It reaches the local and expatriate communities; however, the paper faces strong commercial competition from popular tabloids.

The Straits Times is a state-influenced mainstream broadsheet. It is addressed to the local and expatriate communities. It does not face major commercial competition. 
TABLE 1: Newspapers' Variables

\begin{tabular}{|l|c|c|c|}
\hline & Indonesia & Malaysia & Singapore \\
\cline { 2 - 4 } & $\begin{array}{c}\text { The Jakarta Post } \\
\mathrm{JP}\end{array}$ & $\begin{array}{c}\text { New Straits Times } \\
\text { NST }\end{array}$ & $\begin{array}{c}\text { The Straits Times } \\
\text { ST }\end{array}$ \\
\hline Variables & \multicolumn{3}{|c|}{} \\
\hline State Control & $\begin{array}{c}\text { Relatively } \\
\text { autonomous }\end{array}$ & State influence & State influence \\
\hline Readership & Expatriates & $\begin{array}{c}\text { Local \& } \\
\text { expatriates }\end{array}$ & $\begin{array}{c}\text { Local \& } \\
\text { expatriates }\end{array}$ \\
\hline Competition & Considerable & Strong & Basically none \\
\hline Format & Daily & Daily & Daily \\
\hline
\end{tabular}

The methodology for this paper involves qualitative content analysis and narrative analysis. Content analysis is used to understand the structure and publishing patterns of each newspaper. It involves identifying where the stories originate, who the main informants for the stories are, and the stories' page-placement, i.e. where and how many (Holsti 1969: 27; Gunter 2000: 5). Narrative analysis seeks to draw out themes, characterization, and portrayals of the perpetrators of the acts of violence (Riessman 1993; Ryan and Bernard 2003).

The research concentrates on three days' reporting of the event: 14, 15 and 16 October 2002 (Monday, Tuesday and Wednesday). The bombings were in the early hours of Sunday $13^{\text {th }}$. Full press coverage started on Monday $14^{\text {th }}$. The analysis includes all types of articles related to the bombings, i.e. factual news stories, editorial and commentary pieces and analysis (Picard 1991). The study does not include letters to the editor. There was a combined average of 40 stories per day. The Straits Times from Singapore had the largest amount of stories: over 20. The New Straits Times from Malaysia had just a few stories fewer: around 18; while The Jakarta Post had the fewest: an average of ten per day. Amongst the three newspapers, JP has the fewest pages.

The analysis centered on three basic questions: How were the perpetrators described in the stories? Was there a characterization of the perpetrators? What tendencies did the newspapers' coverage reveal? The answer to these questions help us to understand how societies construct perceptions about whom or what is vulnerable, and who or what is responsible for violence (Waisbord 2002: 205). Many trends have emerged from the articles, but the researcher has tried to concentrate only on the trends closest to the research questions. 
TABLE 2: Content Comparison Between the Three Newspapers

\begin{tabular}{|l|l|l|c|}
\hline & \multicolumn{1}{|c|}{$\begin{array}{c}\text { Indonesia } \\
\text { JP }\end{array}$} & \multicolumn{1}{c|}{$\begin{array}{c}\text { Malaysia } \\
\text { NST }\end{array}$} & \multicolumn{1}{c|}{$\begin{array}{c}\text { Singapore } \\
\text { ST }\end{array}$} \\
\hline $\begin{array}{l}\text { Source of } \\
\text { Stories }\end{array}$ & $\begin{array}{l}\text { Information \& } \\
\text { reaction mainly } \\
\text { from military } \\
\text { authorities, busi- } \\
\text { ness community } \\
\text { and religious } \\
\text { groups. }\end{array}$ & $\begin{array}{l}\text { Commentary main- } \\
\text { ly from govern- } \\
\text { ment officials. }\end{array}$ & $\begin{array}{c}\text { Information from } \\
\text { government officials, } \\
\text { relatives of the vic- } \\
\text { tims, institutionalized } \\
\text { sources*, religious } \\
\text { representatives, ex- } \\
\text { perts, and academics. }\end{array}$ \\
\hline $\begin{array}{l}\text { Origin of } \\
\text { Stories }\end{array}$ & $\begin{array}{l}\text { Stories mainly } \\
\text { written by staff } \\
\text { and a few from } \\
\text { AFP** }\end{array}$ & $\begin{array}{l}\text { Extensive use of } \\
\text { material from AFP } \\
\text { and Reuters** }\end{array}$ & $\begin{array}{c}\text { Staff writers, foreign } \\
\text { news agencies, ana- } \\
\text { lysts and writers from } \\
\text { various countries. }\end{array}$ \\
\hline $\begin{array}{l}\text { Level of } \\
\text { impor- } \\
\text { tance in } \\
\text { page lay- } \\
\text { out and } \\
\text { number of } \\
\text { pages }\end{array}$ & $\begin{array}{l}\text { Stories spread } \\
\text { throughout the } \\
\text { inside pages in } \\
\text { line with the } \\
\text { subjects of exist- } \\
\text { ing sections such } \\
\text { as domestic news } \\
\text { and world news. }\end{array}$ & $\begin{array}{l}\text { Stories spread from } \\
\text { the middle to the } \\
\text { end of the paper, } \\
\text { in the ASEAN and } \\
\text { world news sec- } \\
\text { tions. }\end{array}$ & $\begin{array}{c}\text { The whole of the } \\
\text { first part of the paper } \\
\text { dedicated to stories } \\
\text { on reaction, conse- } \\
\text { quences and analysis } \\
\text { of the event. }\end{array}$ \\
\hline
\end{tabular}

* Institutionalized sources are sources that reinforce the status quo of the dominant group; also known as 'friendly-sources' e.g. Indonesia Committee for Economic Recovery representative.

** AFP Agence France Press, The French-based news agency.

*** Reuters, the British-based news agency. 
TABLE 3: An Overview of the Context in the three Newspapers

\begin{tabular}{|c|c|c|c|}
\hline & $\begin{array}{c}\text { Indonesia } \\
\text { JP }\end{array}$ & $\begin{array}{c}\text { Malaysia } \\
\text { NST }\end{array}$ & $\begin{array}{c}\text { Singapore } \\
\text { ST }\end{array}$ \\
\hline $\begin{array}{l}\text { Concept of } \\
\text { terrorist }\end{array}$ & $\begin{array}{l}\text { Assumed by newspa- } \\
\text { per to be commonly } \\
\text { accepted by readership; } \\
\text { all militant groups } \\
\text { lumped together; con- } \\
\text { tinuous threat. }\end{array}$ & $\begin{array}{l}\text { Assumed by newspa- } \\
\text { per to be commonly } \\
\text { accepted by reader- } \\
\text { ship; all militant } \\
\text { groups lumped } \\
\text { together; continuous } \\
\text { threat. }\end{array}$ & $\begin{array}{l}\text { Assumed by newspaper } \\
\text { to be commonly accepted } \\
\text { by readership; all militant } \\
\text { groups lumped together; } \\
\text { continuous threat. }\end{array}$ \\
\hline $\begin{array}{l}\text { Characteriza- } \\
\text { tion }\end{array}$ & $\begin{array}{l}\text { Performed by official } \\
\text { sources, business com- } \\
\text { munity. }\end{array}$ & $\begin{array}{l}\text { Performed by official } \\
\text { sources. }\end{array}$ & $\begin{array}{l}\text { Performed by official } \\
\text { sources, experts, academics } \\
\text { and writers from other } \\
\text { countries. }\end{array}$ \\
\hline Unique traits & $\begin{array}{l}\text { Focus on the well-being } \\
\text { of foreigners in Indo- } \\
\text { nesia; government inef- } \\
\text { fectiveness identified as } \\
\text { the main problem. }\end{array}$ & $\begin{array}{l}\text { News stories had con- } \\
\text { ciliatory tone, while } \\
\text { editorials were harsh } \\
\text { towards Indonesian } \\
\text { government. }\end{array}$ & $\begin{array}{l}\text { Stories reinforced society's } \\
\text { common assumptions of } \\
\text { good \& bad; journalists } \\
\text { made extensive use of the } \\
\text { words denoting uncertainty } \\
\text { ( 'believe', 'suppose','sources } \\
\text { said', likely'); anxiety and } \\
\text { speculation over what if } \\
\text { JI \& Al Qaeda attacked in } \\
\text { Singapore. }\end{array}$ \\
\hline Similarities & $\begin{array}{l}\text { Lack of concern about } \\
\text { common Indonesian } \\
\text { people; extensive re- } \\
\text { liance on military sourc- } \\
\text { es; focus on foreign } \\
\text { investors' confidence. }\end{array}$ & $\begin{array}{l}\text { Lack of concern about } \\
\text { common Indonesian } \\
\text { people; government } \\
\text { reaction to the event; } \\
\text { focus on internal se- } \\
\text { curity act to maintain } \\
\text { social stability; focus } \\
\text { on foreign investors. }\end{array}$ & $\begin{array}{l}\text { Lack of concern about com- } \\
\text { mon Indonesian people; } \\
\text { message that Indonesia } \\
\text { government has to be } \\
\text { firm, and national security } \\
\text { should be enforced; focus } \\
\text { on foreign investors. }\end{array}$ \\
\hline $\begin{array}{l}\text { Level of emo- } \\
\text { tionality in } \\
\text { the stories }\end{array}$ & Almost none & Low & High \\
\hline $\begin{array}{l}\text { What is mis- } \\
\text { sing }\end{array}$ & $\begin{array}{l}\text { Background informa- } \\
\text { tion }\end{array}$ & $\begin{array}{l}\text { Background informa- } \\
\text { tion, public reaction }\end{array}$ & Background information \\
\hline Differences & $\begin{array}{l}\text { Assurance to interna- } \\
\text { tional community that } \\
\text { Indonesia is serious in } \\
\text { fighting terrorism. }\end{array}$ & $\begin{array}{l}\text { Conflicting messages } \\
\text { on whether SEA is a } \\
\text { hotbed for terrorists. }\end{array}$ & $\begin{array}{l}\text { Message that acts of vio- } \\
\text { lence in the region are con- } \\
\text { nected to Jemah Islamya; } \\
\text { calls for religious tolerance; } \\
\text { emphasis on Singapore's } \\
\text { good medical care. }\end{array}$ \\
\hline
\end{tabular}

\section{Bombers as terrorists}

The newspapers commonly portrayed the bombers as terrorists. There was a common perspective: the enemy, in this case the terrorist, is known, is self-evident and commonly understood (Sederberger 1989). The bombers were presented as a continuous threat. They were also portrayed as militants, and Muslim radicals. The tone of the stories indicated that 
the papers assumed readers knew whom they were talking about, and therefore there was no need to explain why the bombers were labelled as terrorists. The papers did not attempt to eliminate or to reduce the impact of characterizations such as 'Islamic terrorists' or 'religious fanatics' used by their information sources. The three newspapers assumed that the bombers were terrorists, and that everyone was aware of that fact. This could be because the papers relied mostly on people with dominant views for their information as well as on institutionalized sources: those that reinforce the status quo of the dominant group.

\section{Characterization of the bombers}

The enemy was identified by such labels as JI (Jemah Islamya), Al Qaeda, 'Muslim hardliners', 'religious fanatics', and 'Muslim radicals'. These terms were widely used by officials, business representatives, academics, and military sources to refer to the bombers. Labels such as these are powerful symbolic tools to evoke a negative emotional response, especially when they have been accepted as a fact in a particular community. This value-judgement approach in the stories by labelling events or persons as good or as bad is based on the belief system of the establishment (either in the newspapers' editorial line or in the government system behind the newspaper). Enemies are an important aspect of shaping public opinion (Edelman 2001). The problem with media stereotyping, even when paraphrasing officials' statements, is that it can reduce a wide range of differences in people to simplistic categorizations, and can transform assumptions about particular groups of people into 'realities' (Picard 1991: 40). Thus, the militants were classified in the news stories as Muslims radicals, and they were equated to terrorists. This tendency stopped short of recognizing differences in Islamic movements, as well as differences between criminal acts, organized crime and terrorism. As Esposito $(1987,2003)$ has noted, this type of attitude obstructs the public's ability to distinguish between religion and the action of extremists. All militant groups and a wide range of protest activities were lumped together by the newspapers' information sources. For example: 'to take stern measures against all militant groups, some of which have in the past vandalized entertainment centers in the city', (JP, 14 October 2002: 8 in the story titled 'Fall out from Bali blast also felt in JKT', statement by former minister of Tourism and Culture and Chairman of the National Awakening Party, Jakarta Chapter). 


\section{Violence as terrorism}

The designation of violence as terrorism often came from official sources and was woven into the basic fabric of stories by local reports. For example, the first paragraph of the story titled 'Government ups security for public, vital facilities' began with the following statement: 'In anticipation of further terrorist attacks, the government ...' The official comment that the bombing was a terrorist act came in the third paragraph, with Coordinator Minister for Political and Security Affairs Susilo Bambang Yudhono ${ }^{15}$ saying, 'We have some information that the energy plants may be the next target of terrorists' (JP, 14 October 2002: 4). In a story titled 'Innocence lost, RI's day of horror' the writers began with the following statement: 'Powerful explosions rocked Bali... sending the government a violent message of the clear and present danger posed by terrorist groups in the country.' The official perspective that the bombing was an act of terrorism was stated in the $14^{\text {th }}$ paragraph: 'Susilo said the bombing made it clear that there were terrorists active in Indonesia'. (JP, 14 October 2002, front page). Other examples can be drawn from NST in the stories '187 die in Bali bombing' and 'S-E Asia not a terrorist heaven' (14 October 2002: front page, 4). Examples can also be found in the story 'Jakarta blames Al-Qaeda' (ST, 15 October 2002, front page). Fida Mohammad (1999: 315) argues that acts of violence seem more likely to be called terrorism if the victims are foreigners and westerners, as was the case with the Bali bombings. ${ }^{16}$

\section{Failure to Include Background}

The newspapers failed to provide readers with adequate background information on the event, on the societies in which it occurred, on the vulnerability of the victims, or even on the possible causes of the attack. Instead, the papers essentially jumped from reporting on the bombing to discussing the broad threat of terrorism, e.g. the story titled 'Gravity of terrorism shifting to region' (ST, 15 October 2002: 8) and 'Terror sinister symphony wafts closer to home' (ibid: 12). The lack of background denies the reader the chance to understand the context of the bombing and to assess the multiple reasons for the event and its many consequences.

\section{Other Trends Noticed in the Coverage:}

\section{Unique Traits}

Each newspaper displayed some individual traits in its approach to the coverage. The Jakarta Post had a number of stories that emphasized the well-being of foreigners, e.g. '... the police would be in full alert and 
they will increase security to protect the foreign compounds' (Marty Natalegawa, Indonesian Foreign Affairs Ministry spokesman, in 'Expats advised to avoid public places', JP, 14 October 2002: 2). The paper also had a number of stories on the government's ineffectiveness in dealing with terrorism; e.g. 'this incident proves the failure of the national leadership. The government is not seriously running the country...' (Ahmad Syaffi Maarif, chairman Islamic organization Muhammadiya, 'Nation unites in condemning bombing', JP, 12 October 2002: front page).

The New Straits Times had stories with a conciliatory tone toward Indonesia, even as its editorials were harsh towards the Indonesian government. For example, 'The bombings in Bali should not be immediately linked to terrorism as they may be related to developments in Indonesia, Foreign Minister Datuk Seri Hamid Albar said today' ('Bali blasts may have domestic connection', 15 October 2002: 4); 'Dr. Mahathir said bomb blasts had been recorded in many places, not just Indonesia' ( 'Dr M: Terror will win no cause', 15 October 2002: front page). These stories contrasted with 'Indonesia has to do more to fight terrorism, as its neighbours have been urging, to no avail' in the editorial 'Prevention better than cure' (ibid: 10).

The Straits Times focused on the message that the Singapore government was handling the terrorist threat correctly, while stressing the magnitude of the threat to Singapore e.g. 'There was also big relief that Singapore Government had acted well in time', ('Shock and disbelief at attack so close to home', ST, 15 October 2002: 3) and the first line of the same story, 'The horror has hit home. The carnage in Bali has made Singaporeans more forcefully aware of how terrorist violence can in a moment turn the ordinariness of a day into a nightmare without parallel'. This message was also seen in the editorial 'Bali and its after-shocks' (ibid: 12), 'Danger never was this close to home'. Stories evoking emotion, in which shock, sadness, anger are emphasized, have a great potential to influence their readers. They imbue feelings of moral responsibility (be good, do the right thing) and blame - hence the worry of some Muslims in Singapore about being labelled radicals or terrorists ('Shock and disbelief at attack so close to home', ibid: 3 ). This fits with the observation made by Livingston (1994) that identity is the conscious awareness by members belonging to a group and implies some degree of reflection, emotional connection and sharing commonalties.

The Straits Times was the quickest paper to use JI and Al Qaeda to link the bombing with the threat of terrorism. Authorities' practice repeatedly to claim that there are threats or dangers from any specific group to the 
public well-being creates intense fear, and results in the authorities winning public support for repression against domestic groups that might display or incite unrest (Edelman 2001: 47). Public backing for official measures to deal with a source of danger is stronger when the public's basic needs are threatened, as for example the need for safety. 'There was also big relief that Singapore Government had acted well in time', ('Shock and disbelief at attack so close to home', ST, 15 October 2002: 3); another example: 'I feel protected in Singapore, that the government will catch the terrorists and get them out of the way before they do anything' (ibid).

\section{Similarities}

The papers did not address the needs of Indonesian survivors or local people affected by the attacks with the same intensity shown in their coverage of the security issue, foreign victims, investments and on how tourism in Bali is important to Indonesia's economy.

Another similarity is the heavy reliance on official sources. This approach creates structural bias (Chibnall 1977), but often news can only be accessed via official sources. On the institutionalized sources, the journalists failed to ask the 'experts' about the sources of their information or about their connections to the various intelligence agencies. It was not clear whether the journalists had approached sources with views that did not fit the common line.

The New Straits Times and The Straits Times emphasized the importance of national security and the effectiveness of internal security acts in dealing with threats from radicals. National security and the internal security acts are both political symbols that can generate fear among readers. These symbols create anxieties and can easily provoke public opposition to any group that represents or has been identified as a threat to the nation (Edelman 2001; Livingston 1994). Thus, the perceived risk of attacks is enhanced through the development of a culture of fear (Glassner 1999). This provides an understanding of how societies construct perceptions about who or what is vulnerable, and who is responsible. The journalists have perhaps preferred to ignore the use of these acts on the ground of human rights.

\section{Emotion}

The level of emotion was measured by the amount of stories dedicated to accounts portraying shock, sadness, and anger. The Straits Times had the largest amount of stories appealing to emotion, including illustrations (ST, 14 October 2002: front page 'Charred and mangled bodies...'; 
mangled bodies, on page ibid: 7; 15 October 2002, front page). The NST limited the emotional impact by using less graphic pictures, and less descriptive emotional loaded stories.

\section{Differences}

The most striking difference comes from the New Straits Times with its conflicting message about whether or not terrorism is rooted in Southeast Asia. For example:

'It's sad news. The bombings have caused many deaths. They must have been carried out by terrorists' statement by Deputy Prime Minister Datuk Seri Abdullah Ahmad Badawi, ('S-E Asia not a terrorist heaven', NST, 14 October 2002: 4). Then 'The bombings in Bali should not be immediately linked to terrorism as they may be related to developments in Indonesia' statement made by Foreign Minister Datuk Seri Syed Hamid Albar ('Bali blast may have domestic connection', NST, 15 October 2002: 4). In the same article Defense Minister Datuk Seri Najib Tun Razak said, 'The attacks prove that the region is facing threats from terrorists...'

The New Straits Times urged the Indonesian government to deal with 'religious fanatics', while at the same time positively emphasizing the social stability in Malaysia.

The Straits Times had a number of stories on Singapore's medical help and good quality service. The tone of the stories leaves a perception of a public relations exercise coated with a level of human interest. This could be in line with the idea that Singapore is selling itself as a medical destination in Asia (Singapore Tourism Board 2003). Examples can be drawn from the stories 'Singapore doctors treating Balinese' (ST, 16 October 2002: A2); 'Families keep tense vigil over victims' (ibid); 'Couple's wedding party lost' (ibid.).

The Straits Times used the Bali bombing reporting to emphasize the need for religious tolerance, stress the collective responsibility to prevent terrorist attacks in Singapore, and pressure the Indonesian government to implement internal security measures to deal with radicals.

The Jakarta Post stressed the need to assure investors and the international community that Indonesia is serious in fighting terrorism. Examples include: '.. unless this government can successfully address the imminent and real threat of terror, any remaining confidence in Indonesia's business and investment environment will certainly fade away' (JP, 16 October 2002: 6, 'Lessons from the Bali blast' statement made by Bantaro Bandoro); 'The business community urged the government on Monday 
to take swift action against terrorists to contain the damage caused by the Bali bombing attack to the country's economy', ('RI must swiftly act against terrorists-Businessmen', JP, 15 October 2002: 13). And, 'The government also will cooperate with the business sector and international event organizers to ensure that convention and conferences scheduled for Bali next year can go ahead as planned, he said'. (ibid.).

\section{Conclusion}

The characterization of the bombers as terrorists and Muslim radicals came from the dominant sources of information. Considering that government officials and intellectuals in the three countries consistently have stated that Muslims in the region are generally moderate, why do they refer to the perpetrators of the bombing by their religion? Officials and intellectuals are expected to avoid such religion classification, even if the bombers appeal to religiosity to justify their acts of violence. This finding is important, especially when the religious classification comes from elite groups in countries with majority Muslim populations such as Indonesia and Malaysia. Nevertheless, even in these countries there are sources and journalists who would argue that there is nothing wrong in calling the bombers terrorists or referring to the bombers as Muslims.

The coverage in the three papers displayed favoritism, since most of the information was based on the dominant view of the society's elite. The lack of alternative views and the lack of background information obstructed the reader's understanding of the bombing's link to the 'war on terror'. Furthermore, the coverage was used by its producers to send messages and propagate beliefs about a broad range of domestic and international issues. The Jakarta Post demonstrated that it had effectively become an arm of a special interest lobbing group, the business community. The New Straits Times and The Straits Times played up the security angle, reflecting the concerns of the governments in Malaysia and Singapore.

Sonia Ambrosio de Nelson is a Ph.D. candidate at the Department of Sociology, National University of Singapore. She is a journalist for the media in Brazil. 


\section{APPENDIX}

The observations below were drawn from the newspapers' articles. They are trends that have appeared with a certain frequency in the three days coverage of the bombing but have not been dealt with in this paper.

\section{From The Jakarta Post}

Criticism of the central government/ leadership skills

Pressure on the government to take action against Muslim hardliners

Emphasis on the urgency to arrest the perpetrators

Concern with the exodus of foreign investors

Concerned with the well-being of foreigners in the country

Concerned with the security of key installations

Resolve the case immediately

Were the military involved in the attacks?

The introduction of law to curtail individual freedom

\section{From New Straits Times}

Speculation on the bombing having a domestic connection

Condemnation of UK and US for not dealing with the root of terrorism

Not to link the bombing to terrorism

Concern with continuous economic success

Our (Malaysian) social order is stable

The efficiency of the use of Internal Security Act-ISA

Use of ISA to arrest 'acquaintances' of bin Laden

Indonesia to heed international pressure

Indonesia has to deal with 'religious fanatics'

Indonesia to put aside civil liberties and democracy and act against suspect terrorists, even when lacking concrete evidence

Condemnation of discriminatory acts in the entertainment industry in Bali against Indonesian nationals

Muslim-Hindu relationship in Bali (Megawati's roots)

Stories had conciliatory tone in sharp contrast with harsh editorials

\section{From The Straits Times}

Bombing linked to Jemmah Islamiya and Al Qaeda groups

Terrorism could undermine inter-religious relations and turn away investors Singaporean Muslims worried to be labeled radicals or terrorists

Concern with economic consequences and foreign investment

Experts and academics make connections between Muslims and violence 
Bring fear near 'home' (Singapore) - what if it had happened here?

Religious tolerance - to create the Religious Harmony Act

We are doing the right thing

Indonesia should implement an emergency presidential decree

Internal Security Act to deal with radicals

Megawati's roots (Hindus vs Muslims)

\section{NOTES}

Acknowledgements. Thanks to those who made comments on the paper presented at the $6^{\text {th }}$ ASEAN Inter-University Seminars held in Penang, Malaysia in May 2004; to Professors Hing Ai Yun and Leong Wai Teng of the Department of Sociology, National University of Singapore; and to those who contributed to the paper's revision.

1 Southeast Asia covers 4.5 million square kilometers, and encompasses 10 countries: Brunei, Cambodia, Indonesia, Laos, Malaysia, Myanmar (Burma), the Philippines, Singapore, Thailand and Vietnam. The region is bounded by the Philippines to the east, to Thailand heading west, Myanmar to the north, and the Indonesian archipelago to the south. These nations have a combined population of 500 million, an aggregate gross domestic product of US $\$ 737$ billion and total trade of US\$720 billion. The 10 countries are members of the Association of Southeast Asian Nations (ASEAN). Data from the Asean website, www.aseansec.org

2 The region is diverse, in terms of population, land mass, GDP per capita, government systems and religion, to name a few. There are countries as small as Singapore, covering 633 square kilometers, to giants such as Indonesia, at 1.9 million square kilometers. The oil-rich country of Brunei has a population of 354,500 people, while there are 220 million Indonesians. Catholicism is the predominant religion in the Philippines; Buddhism in Thailand and Myanmar; Islam in Indonesia and Malaysia. Cambodia has the lowest GDP per capita at US\$704, and the highest belongs to Singapore at US $\$ 23,065$.

3 At present, there are an estimated 230 million Muslims in Southeast Asia, the majority of them in Indonesia, home to the world's largest Muslim nation. Among the countries where Islam is politically significant are Indonesia, Malaysia, the Philippines, and Singapore.

4 According to the World Press Freedom Rankings released in October 2004, Indonesia was ranked $117^{\text {th. }}$ In 2003 Indonesia was ranked $110^{\text {th }}$, a big fall from the position of $57^{\text {th }}$ in 2002. Malaysia was ranked $122^{\text {nd }}$. In the previous year Malaysia was ranked $104^{\text {th }}$, an improvement from $110^{\text {th }}$ in 2002. In 2004 Singapore was ranked $147^{\text {th }}$ whereas in 2003 the media in the city-state was ranked $144^{\text {th }}$. Singapore was not ranked in the previous year. The perception that the press freedom in the three countries is worsening should be the matter of another study.

5 The number of press publications has increased from less than 29 in 1997 to over 100 in 2000, after former president B.J. Habibe lifted the licensing system (Heryanto and Adi 2001).

6 Indonesian military authorities launched an offensive against separatist rebels in Aceh Province in May 2003, and have since pursued a strict policy of controlling media access to the conflict area. Reporters were officially banned from contacting 
rebels and from visiting rebel areas. Maj. Gen. Sjafrie Sjamsuddin, chief of Information for Indonesia Armed Forces, in a press briefing in Jakarta in 20 June 2003, to unveil formally the tight restriction in the media coverage in Aceh said, 'These regulations were sent to us by the U.S. Pacific Command. It is what they used in Iraq. Of course, we have adapted them to our local environment'. Information from the Committee to Protect Journalists.

7 New Straits Times, 30 September 2003, author Abdul Razak Ahmad. Title 'Special role media play in Singapore'.

8 The Asian Wall Street Journal, Far Eastern Economic Review, Time, Asiaweek, Bloomberg all resigned themselves to the special conditions of operating in Singapore after being in dispute about, and penalized for, their coverage of Singapore. These disputes not only involved the content of articles but also the Singapore government's firmness on the right to have replies to such content published in unedited form in the offending publications.

9 Muslims comprise 15 percent of the population in Singapore (Kassim 2002). Muslims comprise 88.9 percent of the population in Indonesia. 65 percent of the population in Malaysia is Muslim.

10 White Paper: The Jemaah Islamiya Arrests and The Threat of Terrorism, Singapore Parliament Presentation, 7 January 2003.

11 Date: 18.05.50 Cabinet Malaya Committee Meeting FZ 1017/11G: FO371/84478; official memo from the Secretary of Defense, 20 May 1952, CO 1022/48. Carruthers 1996.

12 White House Press Conference, 17 September 2001.

13 A Saudi Arabian dissident.

14 President George W. Bush speech to the American Congress in 20 September 2001.

15 Since then, Susilo Bambang has been elected President of Indonesia in the first-ever direct presidential election in the country held on 20 September 2004

16 There were 7 Americans and 88 Australians amongst the more than 200 victims from 22 nations, including a large number of Indonesians.

\section{REFERENCES}

Acharya, Amitav 2000. The Quest for Identity: International Relations of Southeast Asia, Regional and Regionalism in the Making of Southeast Asia, Oxford: Oxford University Press.

Anuar, Mustafa K. 2000. Country Report. In Media \& Democracy in Asia, Asian Media Information and Communication Centre.

Asian Communication Handbook 2003. Asian Media Information and Communication Centre and School of Communication and Information Nanyang Technological University.

Atkins, Stephen E. 1992. 'Terrorism: A Reference Handbook'. In Contemporary World Issues: Library of Congress Cataloguing-in Publication Data.

Carruthers, Susan 1996. 'Reporting Terrorism: The British State and the Media, 1914-94. In Ian Stewart and Susan Carruthers (eds), War, Culture, and the Media: Representations of the Military in $20^{\text {th }}$ Century Britain. Flick Books.

Chibnall S. 1977. Law and Order News: An Analysis of Crime Reporting in the British Press. London: Tavistock Publications. 
Chonkittavorn, Kavi 2002. 'Southeast Asia Media Struggle to be Free', Nieman Reports: Cambridge, Vol. 56 (2): 2, 59-60.

Croteau, David 2000. Media Society - Industries, Images, and Audiences, $2^{\text {nd }}$ edition. Pine Forge Press.

Edelman, Murray 2001. The Politics of Misinformation, Cambridge: Cambridge University Press.

Esposito, John (ed.) 1987. Islam in Asia: religion, politics and society, New York: Oxford University Press.

-2003. 'Beyond the Headlines', Harvard International Review, Vol. 25 (2) Summer: 16-20.

Foucault, M. 1978. The History of Sexuality: An Introduction, Vol. 1. New York: Random House.

George, Cherian 2002. 'Singapore: Media at the Mainstream and the Margins'. In Russell H.K. Heng (ed.), Media Fortunes - Asean States in Transition - Changing Times. Singapore: Institute of Southeast Asian Studies.

-2003. 'The Internet and the Narrow Tailoring Dilemma for "Asian Democracies"', The Communication Review, Vol. 6 (3): 247-268.

Glassner B. 1999. The Culture of Fear: Why Americans are Afraid of the Wrong Things. New York: Basic Books.

Gunter, Barrie 2000. Media Research Methods. London: Sage Publications.

Hafez, Kai 2000. Islam and the West in the Mass Media - Fragmented Images in a Globalizing World. Hampton Press, Inc.

Harsono, Andreas 2000. 'Indonesia: Dancing in the Dark'. In Louise Williams and Roland Rich (eds) Losing Control: Freedom of the Press in Asia, Canberra: Asia Pacific Press: 74-92.

Hassan, Sharifah Zaleha Syed 2001. 'Islamization and the Emerging Civil Society in Malaysia - A Case Study'. In Mitsuo Nakamura, Sharon Siddique, Omar Farouk Bajunid (eds), Islam and Civil Society in Southeast Asia. Singapore: Institute of Southeast Asian Studies.

Hatchen, William A. 1996. The World News Prism - Changing Media of International Communication, $4^{\text {th }}$ edition. Iowa State: University Press.

Held, Virginia 1997. 'The Media and Political Violence', Journal of Ethics, Vol. 1 (2): 187.

Heng, Russell Hiang-Khng 2002. 'Media in Southeast Asia: A Literature Review of Post 1980 Developments'. In Media Fortunes - ASEAN States in Transition, Changing Times. Singapore: Institute of Southeast Asian Studies.

Herman, Edward S. and Noam Chomsky (eds) 1999. 'Manufacturing Consent'. In News: A Reader. Oxford: Howard Tumber.

Heryanto, Ariel and Stanley Yoseph Adi 2001. 'The Industrialization of the Media in Democratizing Indonesia', Contemporary Southeast Asia, Vol. 23 (2) August.

Holsti, Ole R. 1969. Content Analysis for the Social Sciences and Humanities. AddisonWesley Publishing Company.

Irwin, Harry 1966. Communicating with Asia - Understanding People and Customs. Allen \& Unwin Pty Ptd.

Iyer, Venkat 2004. 'Terrorism and the Media: Is Self-regulation the Answer?'. In Media in a Terrorized World - Reflections in the Wake of 9 11. London \& New York: Marshall Cavendish: Eastern Universities Press.

Jenkins Philip 2003. Images of Terror - What We Can and Can't Know about Terrorism. Walter de Gruyter.

Karim, H. Karim 2000. Islamic Peril: Media and Global Violence. Black Rose Books.

Kingsbury, Damien 2001. South-East Asia A Political Profile. Oxford University Press.

Khee, Hoo Ban 2000. 'Media and Democracy in Malaysia'. In Media and Democracy in 
Asia, Singapore: Asian Media Information and Communication Centre. Livingston Steven 1994. The Terrorism Spectacle. Western Press.

Manning, Peter K. 1999. 'Reflections - The Visual as a Mode of Social Control'. In Jeff Ferrell and Neil Websdale (eds), Making Trouble - Cultural Constructions of Crime, Deviance, and Control. Aldine de Gruyer.

McCargo, Duncan 2003. Media and Politics in Asia Pacific. London: RoutledgeCurzon.

Menon, V. 1994. Press Systems in ASEAN States. Singapore: Asian Mass Communication Research and Information Centre.

Mohammad, Fida 1999. 'Jihad as Terrorism - The Western Media and the Defamation of the Qu'ran'. In Jeff Ferrell and Neil Websdale (eds), Making Trouble - Cultural Constructions of Crime, Deviance and Control, New York: Aldine De Gruyer.

Nacos, Brigitte L. 2000. 'Accomplice or Witness? The Media's role in Terrorism - Is the Media Terrorism's 'Oxygen'? - A Critical Examination of How Terrorists Rely on and use Various Media', Current History Vol. 99 (636).

Nain, Zaharom, 2002. 'The Media and Malaysia's Reformasi Movement'. In Russell H.K. Heng (ed.), Media Fortunes - ASEAN States in Transition, Changing Times, Singapore: Institute of Southeast Asian Studies.

Nakamura, Mitsuo, Sharon Siddique and Omar Farouk Bajunid (eds) 2001. Islam and Civil Society in Southeast Asia, Singapore: Institute of Southeast Asian Studies.

Picard, Robert G. 1991. 'The Journalist's Role in Coverage of Terrorist Events'. In A. Odasuo Alali and Kenoye Kelvin Eke (eds), Media Coverage of Terrorism - Methods of Diffusion. Lodon: Sage Publications.

Picard Robert and Adams Paul 1991, 'Characterization of Acts and Perpetrators of Political Violence in Three Elite U.S. Daily Newspapers'. In A. Odasuo Alali and Kenoye Kelvin Eke (eds), Media Coverage of Terrorism - Methods of Diffusion. London: Sage Publications.

Print Media in ASEAN 1998, ASEAN Studies Publications Series. Phase I-c: Asean Committee on Culture and Information.

Riessman, Catherine Kohler 1993, 'Narrative Analysis'. Qualitative Research Methods Vol. 30.

Rodan, Garry 2000. 'Asian Crisis, Transparency and the International Media in Singapore'. The Pacific Review Vol. 13 (2): 217-242.

-2003. 'Embracing Electronic Media but Suppressing Civil Society: Authoritarian Consolidation in Singapore'. The Pacific Review Vol. 16 (4): 503-524.

Ruby, Charles L. 2002. 'The Definition of Terrorism'. Analyses of Social Issues and Public Policy. Vol. 3 (1) December: 9-14.

Ryan, Gery W. and H. Russell Bernard 2003. 'Techniques to Identify Themes'. Field Methods, Vol. 15 (1) February: 83-109.

Said, Edward 1997. Covering Islam - How the Media and the West Experts Determine How We See the Rest of the World. London: Vintage Books.

Stenvall, Maija 2003. 'An actor or an Undefined Threat? The role of 'Terrorist' in the Discourse of International News Agencies'. Journal of Language and Politics, Vol. 2 (2): 361-404.

Sederberg, Peter C. 1989. Terrorist Myths Illusion, Rethoric and Reality. Prentice Hall, Inc.

Singapore Tourism Board, 20 October 2003. 'Singapore set to be Healthcare Service Hub of Asia', Press Release.

Sorel, Jean Marc 2003. 'Some Questions About the Definition of Terrorism and the Fight Against Its Financing', European Journal of International law, Vol. 14 (2) April: 365-378. 
Tan, Andrew 2001. 'The 'New' Terrorism: How Southeast Asia Can Counter It'. In Uwe Johannen, Alan Smith and James Gomez (eds), September 11 \& Political Freedom -Asian Perspectives. Select Publishing.

Thayer, Carlyle A. 2004. 'Radical Islam and Political Terrorism in Southeast Asia'. Paper presented at ISEASS-SSAAPS Winter Seminar, 'Globalization and Its Counter Forces', 23-27 February. Singapore: Institute of Southeast Asian Studies.

Uhlin, Anders 1997. Indonesia and the 'Third Wave of Democratization': The Indonesian Pro-Democracy Movement in a Changing World. New York: St. Martin's Press.

Waisbord, Silvio 2002. 'Journalism, Risk, and Patriotism'. In Barbie Zelizer and Stuart Allan (eds), Journalism After September 11. London: Routledge.

White House, Press Conference. www.whitehouse.gov.news/releases/2001/09/ 20010920-8html

Wong K. 2004. 'In Asia-Based Development Journalism and Political Elections: Press Coverage of the 1999 General Elections in Malaysia'. Gazette Vol. 66 (1) February: $25-40$. 